AL IBTIDA: JURNAL PENDIDIKAN GURU MI (2020) Vol 7 (1) : 132-147

DOI: http://dx.doi.org/ 10.24235/al.ibtida.snj.v7i1.6147

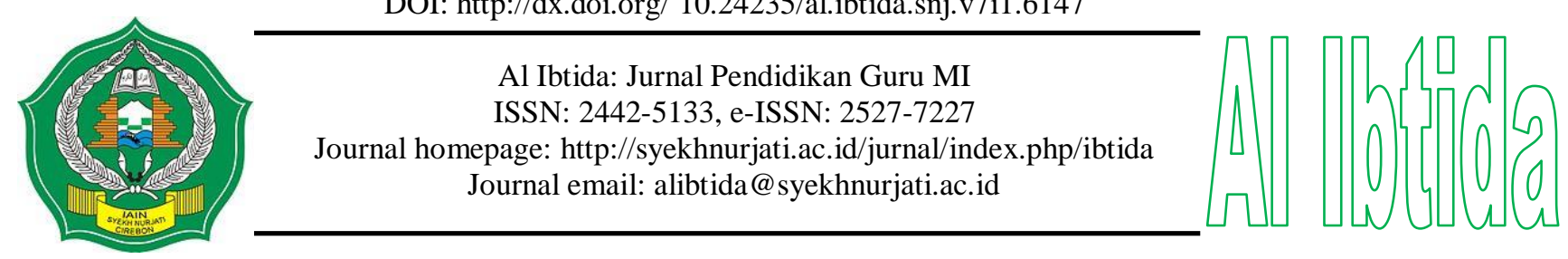

\title{
The Analysis of Self-Efficacy and Classroom Management as Contributors to Teacher Personality of Madrasah Ibtidaiyah
}

\author{
Fidrayani* \\ *Department of Madrasah Ibtidaiyah Teacher Education, Faculty of Tarbiyah dan Teacher Training, \\ UIN Syarif Hidayatullah Jakarta, Indonesia \\ Email: fidrayani7276@uinjkt.ac.id \\ Eti Hadiati** \\ **Department of Islamic Education, Faculty of Tarbiyah dan Teacher Training, \\ UIN Raden Intan Lampung, Indonesia \\ Email: etihadiati@radenintan.ac.id
}

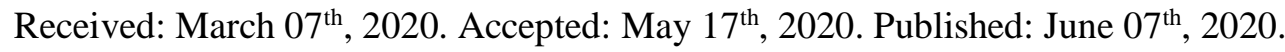

\begin{abstract}
A teacher's low self-efficacy causes a weak support of personality competencies for success in learning. This study aims to analyze self-efficacy and classroom management on the personality of Madrasah Ibtidaiyah teachers. The subjects of this study were 25 Madrasah Ibtidaiyah teachers in South Tangerang City, Banten Province who already have teaching certificates. Data collection techniques used questionnaires and interviews. Meanwhile the research data were analyzed using descriptive analysis, starting from data reduction, data presentation, and data conclusion. The results showed that Madrasah Ibitidaiyah teachers in South Tangerang have a good competencies, i.e the percentage of good pedagogical competencies was in the range $50 \%-100 \%, 80 \%-100 \%$ for good personality competence, $68 \%-100 \%$ for good social competence, and $96 \%-100 \%$ for good professional competence. Internal locus of control Madrasah Ibtidaiyah teachers in the city of South Tangerang are in the very high, high and medium categories. While external locus of control is in the low category. This shows that the Madrasah Ibtidaiyah teachers had the belief that they are able to face challenges and threats that come from the environment and the ability to solve problems with high confidence so that all problems can be overcome properly. Therefore, the development of teacher's self-efficacy should get more attention, because it is a factor that can support successful learning
\end{abstract}

Keywords: self-efficacy, classroom management, teacher personality.

\begin{abstract}
Abstrak
Efikasi diri seorang guru yang rendah menyebabkan lemahnya dukungan kompetensi kepribadian terhadap keberhasilan dalam pembelajaran. Penelitian ini bertujuan untuk menganalisis efikasi diri dan manajemen kelas terhadap kepribadian guru Madrasah Ibtidaiyah. Subjek penelitian ini sebanyak 25 guru Madrasah Ibtidaiyah di Kota Tangerang Selatan, Provinsi Banten yang sudah memiliki sertifikat mengajar. Teknik pengumpulan data yang digunakan adalah angket dan wawancara. Sementara
\end{abstract}


itu data hasil penelitian dianalisis menggunakan analisis deskriptif, mulai dari reduksi data, penyajian data, dan penyimpulan data. Hasil penelitian menunjukkan bahwa guru Madrasah Ibitidaiyah di Kota Tangerang Selatan memiliki kompetensi pedagogik yang baik, yakni prosentasenya antara 50\%-100\%, kompetensi kepribadian yang baik, prosentasenya antara 80\%-100\%, kompetensi sosial yang baik, prosentasenya antara 68\%-100\%, dan kompetensi profesional yang baik pula, yakni prosentasenya antara 96\%-100\%. Locus of control internal guru madrasah ibtidaiyah di kota Tangerang Selatan berada dalam kategori sangat tinggi, tinggi, dan sedang. Sementara locus of control eksternal dalam kategori rendah. Hal ini menunjukkan bahwa guru madrasah ibtidaiyah memiliki keyakinan bahwa ia mampu menghadapi tantangan dan ancaman yang berasal dari lingkungan luar dan mampu menyelesaikan masalah dengan kepercayaan diri yang tinggi sehingga semua masalah dapat diatasi dengan baik. Oleh karena itu, pengembangan efikasi diri guru harus mendapat perhatian yang lebih besar, karena merupakan salah satu faktor yang dapat mendukung keberhasilan proses pembelajaran.

Kata kunci: self-efficacy, manajemen kelas, kepribadian guru.

\section{INTRODUCTION}

The teacher is the main actor who plays an important role in the teaching and learning process. Schools with adequate facilities, perfect curriculum, or good students are only a few small tasks that must be done by the teacher. The teachers must have and balance the expertise they have with other abilities such as the ability to follow developments in science, values and philosophical background, as well as their individual characteristics. The success of teachers in the learning process is determined by the self-efficacy owned by them. People with high self-efficacy can choose to make more effort and are not easily discouraged (Yuliyanto, Turmudi, Agustin, Putri, \& Muqodas, 2019).

Teacher efficacy has been defined as the extent to which a teacher believes can influence students' behavior and academic achievement (Friedman \& Kass, 2002). Selfefficacy as the confidence of a teacher in their own abilities and skills to teach effectively and apply their knowledge in the teaching process (Veronika et al., 2018). Rosyidah \& Ratnasari (2013) in their research explained that one of the reasons teachers did not pass the competency test was suspected of personality factors including the lack of teacher teaching efficacy. The teacher's personality in question is efficacy. As expressed by Sudarma in Erawati (2012), there is a tendency for teacher mentalities to be pessimistic, fatalist, and pragmatic. This is caused by inadequacy and reluctance to try as hard as possible as a teacher. Research results also shows that teachers who have high efficacy have the ability to use all their potential and resources for educational success (Nunn \& Jantz, 2009).

The efficacy of teaching is an important element in teacher education. Self-efficacy for teachers is the ability to complete tasks and believe in success. The success of learning depends on consistency between planning learning goals and the teaching practices. High 
level teacher efficacy is very beneficial for improving student learning outcomes (Nunn \& Jantz, 2009), because highly-qualified teachers have a great psychological energy to devote all their resources and potential to creat success learning. Techers in a good efficacy can take responsibility for their own achievements (Evers, Brouwers, \& Tomic, 2002). They are prominent figures in the educational system both statistically and in their potential for influencing educational outcomes (Kim, Jorg, \& Klassen, 2019).

Ebuenga-Amora (2016) in her research revealed that teachers who have good efficacy will have a positive impact on their students. The positive impact eventually led to the student's ability to understand mathematics even though they thought the difficult lesson. The efficacy of teacher has an impact on students including the management of elementary school teacher classes. The teacher's self-efficacy is conceptually distinguished from the collective teacher's efficacy and the external control. Teacher self-efficacy is closely related to the effectiveness of the collective teacher and teacher fatigue (Skaalvik \& Skaalvik, 2007). Gibson \& Dembo (1984) stated that teachers who have high self-efficacy are more focused and have different feedback than teachers who have low self-efficacy. The consequences affect their behavior; trust in students' abilities and the amount of effort they make in learning activities.

Social cognitive learning theory highlights the idea that most human learning takes place in the social environment. By observing others, people gain knowledge about rules, skills, strategies, beliefs, and attitudes. People also learn about the usefulness of behavior by observing the model and its consequences and they act according to their beliefs about the expected outcome of actions. Social cognitive theory is a direct response to behaviorism. Bandura (1997) began to build his theory of social learning by identifying three areas of weakness in Behaviorism: a) The limited types of behavior that made it possible to conduct research in laboratory type settings, b) the fact that these theories were not able to explain the acquisition of new responses, c) which were dealt with only one type of learning, namely direct learning, where learners respond and experience the consequences. Bandura (1997) called this type of learning as instantaneous matching, while indirect learning as delayed matching in which the student observes behavior and then applies the same type of it.

Bandura (1997) proposed the concept of reciprocal determinism, in which cognitive processes, behaviors, and contexts all interact, each factor simultaneously influencing and being influenced by the other. Cognitive processes refer to all the characteristics that have been studied before, including beliefs, expectations, and the characteristics of personality. Behavior refers to anything we do that can be valued or punished. Finally, the context in 
which the behavior occurs refers to the environment or situation, which includes reward / punishment stimuli. This theory is important because it moves away from the idea that the environment a influences a person's behavior lonely. In contrast, Bandura (1997) hypothesizes that the relationship between behavior and environment is bidirectional, meaning that both factors can influence each other. In this theory, humans are actively involved in creating environments that affect their own development and growth.

The social learning theory represents the integration of learning and personality theory (Phares, 1976). According to Rotter (1966), people are likely considering the consequences of their actions in certain situations and their act according to beliefs. Rotter (1966) suggests that self-efficacy is influenced by locus of control. Locus of control is the extents in which individuals believe that they can control events affect them, both internal and external. Rotter (1966) expanded on Bandura's idea of reciprocal determinism, and he developed the term locus of control to describe how individuals perceive their relationship with the environment. Different from self-efficacy, which involves our belief in our own abilities locus of control refers to our beliefs about the strength we have during our lives, and is a cognitive factor that influences personality development. Locus of control can be grouped along the spectrum from internal to external, where someone falls along the spectrum determines the extent to which they believe that it can affect the events around them.

Furthermore Rotter (1966) explains that the internal factor of locus of control is the ability to control the consequences of behavior regarding to academic achievement, good interpersonal relationships, strong efforts to learn, positive attitudes towards tasks, avoiding smoking, avoiding hypertension and heart attacks . External factors are the consequences of behavior outside of control, for example choosing not to be like other people, weak business towards health, low self-regulation, preferring to be in a comfort zone. Effective classroom management continues to be a major concern and challenge to many teachers (Evertson \& Neal, 2006), with difficulties in managing student behavior cited as one of the leading causes of teacher attrition (Brouwers \& Tomic, 2000).

Bandura's theory concerning on the seven dimensions of efficacy, four groups are obtained. First, the efficacy of teaching (instructional self-efficacy) reveals pedagogical competence. Second, the efficacy of disciplinary self-efficacy is used to reveal personality competencies. Third, efficacy influences decision making (efficacy to influence decision making), efficacy affects school resources (efficacy to influence school resources), efficacy involves parents (efficacy to enlist parental involvement), and efficacy involves community (efficacy to enlist community involvement) in line with social competence. Fourth, the 
efficacy of creating a positive school condition (efficacy to create a positive school climate) in line with professional competence. Sources of efficacy include the experience of mastering a competency (enactive mastery experiences), the experience of seeing the consequences that occur in others (vicarious experiences), verbal persuasion (verbal persuasion), and physiological and affective conditions (Bandura, 1997).

Efficacy and class management have a clear relationship as stated by Freeman and Kass in Moran, Megan, Hoy, \& Woolfolk (2001) that teacher efficacy is divided into two areas, namely: a) the class area, including student teaching and learning processes, b) doing organizational tasks, being part of organization and social processes, the scope is outside the classroom. There are three determinants of teacher efficacy, namely instructional strategies, classroom management and student involvement. The strategy of giving instruction is formed from the way the teacher explains the material, gives questions and doing an assessment of students. Class management is formed from the teacher's ability to ensure students participate in all learning activities and maintain class balance (maintaining class order from students who deviate). Student involvement is also one of the benchmarks of teaching efficacy which is formed from the visibility of students playing an active role in class (Moran et al., 2001).

Culture influences efficacy based on fundamental systems and institutions of all spheres of society, including at home, school, work and student's community. Each situation in a different context also found different efficacy. Understanding how culture influences the teaching efficacy can explain how to measure the efficacy of each different culture. Hofstede (1991) suggested four dimensions of cultural differences, namely: a) individualism/ collectivism. Collectivism is the view that a person's success cannot be separated from his group, whereas individualism on the contrary sees that one's success is only determined by him. b) Gap of power. In cultures with large power gaps, people are expected to accept the situation. Conversely, people who have a small gap more easily distribute power, c) masculinity/femininity, masculine culture trying to maximize the difference between men and women. Men are expected to be more successful, assertive, ambitious and competitive while women are more expected to care for children and are weak. Women are not expected to have professional jobs and positioned as a second class of human.

Some previous studies related to self-efficacy was conducted by Panadero, Jonsson, \& Botella (2017) conclude that self-efficacy can be influenced by self-assessment; Honicke \& Broadbent (2016); Stajkovic, Bandura, Locke, Lee, \& Sergent (2018) conclude that academic self-efficacy effect on academic performance; Skaalvik \& Skaalvik (2017); Williams \& Rhodes (2016) conclude that self-efficacy can motivate the teacher and do something you 
want; Frazier, Bendixen, \& Hoskins (2019) conclude that self-efficacy contributes to prospective teachers' career decision-making; Zimmerman, Schunk, \& DiBenedetto (2017) conclude that self-efficacy contributes to self-regulation of learning and performance; and Yoo (2016) conclude that teacher efficacy effect on professional development.

Difference from some previous studies above, this research aims to analyze selfefficacy and classroom management on the personality of Madrasah Ibtidaiyah teachers in Tangerang Selatan City, Banten Province, which are more than 1500 people are Madrasah Ibtidaiyah teachers. Among these teachers are around 500 teachers who have S1 qualifications and have passed certification program. From these data, the researcher needs to get description of self-efficacy and classroom management on the personality of Madrasah Ibtidaiyah teachers.

\section{METHODS}

This study was conducted at Islamic Elementary School (MI) of South Tangerang City consisting of five Madrasah Working Groups (KKM). The study was conducted for three months starting from July to October 2018 with number of research subjects are 25 people spread in five Madrasah Working Groups. There were 6 men and 19 women. The range of certification is 7 people ( $0-4$ years), 15 people (5-8 years) and 3 people (9-12 years). It was conducted using a qualitative / ethnographic approach with the following steps: 1) preparation stage, 2) field stage, 3) data processing.

First, preparation stage. In this stage, researchers prepare a) research designs; b) research conducted is a problem that already exists and it is inherent to the subject that continues and can be observed. Focus on observing people's behavior and organizational activities; c) before going down the field, researchers looked for teacher data to be studied. From the data obtained, there are five KKM (Madrasah Working Group) in the City of South Tangerang, namely Ciputat Timur, Ciputat, Serutu, Pondok Aren, and Pamulang. From the five KKM, researcher selected 25 teachers who have been certified and represent the group. After the data is obtained, the researcher prepares steps to collect data; d) take care of licensing. Licensing of the bureaucracy affects the environment, in this case researchers will be considered as foreign. Therefore, it is necessary to obtain permits, both from those who give authority at the research location. In addition, tin avoiding stiffness research data taking, the openness of the subject to the presence of researchers; e) Prepare the instruments. The presence of the researcher is as the data collector. Therefore sensitivity and responsiveness to responses from the environment are needed so that it can present meaningful data. The diversity of data to be taken in research is also the responsibility of the researcher; f) research 
ethics. As people entering certain communities or environments researchers must follow rules or ethics in that environment. Physical, mental and psychological preparation must be prepared by the researcher.

Second, field stage. Understanding the research setting is needed in observing and to interact with others. Adjust the appearance, habits, or customs of the place under study. Limiting the time of research and the availability of data that has been collected before. Researchers as the main instrument must put themselves in a neutral position to avoid bias with the subject in extracting the required data. Third, data processing stage. Stage of data processing is divided into three stages, data reduction, data presentation and verification, data analysis and checking its validity. Then it will be described in the data processing procedure clearly.

Data collection technique in this study used questionnaire, interviews, and documentation. The questionnaire is prepared based on Bandura's teaching efficacy and class management theory. The interview grid is compiled based on personality theory and documentation studies in the form of lesson plan (RPP) and direct observation in the classroom to assess the extent to which the teacher prepares the learning. The questionnaire sheet used in this study is based on First, efficacy in teaching (instructional self-efficacy) reveals pedagogical competence. Second, disciplinary self-efficacy is used to reveal personality competencies. Third, efficacy influences decision making (efficacy to influence decision), efficacy influences school resources (efficacy to influence school resources), efficacy to enlist parental involvement, and efficacy involving community (efficacy to enlist community involvement) in line with social competence. Fourth, the efficacy of creating a positive school climate (efficacy to create a positive school climate) is in line with professional competence. Sources of efficacy include experience mastering a competency (enactive mastery experiences), experience seeing consequences that occur in others (vicarious experiences), verbal persuasion, and physiological-affective conditions (Bandura, 1997).

Data processing procedures in this study used the model of Miles \& Huberman in Dull \& Reinhardt (2014) with the following flows: 1) data reduction. Activities summarize, choose the main things, focus on the important things, and looked for themes and patterns. Reduced data will provide a clearer picture and make it easier to do further data collection and search if it is necessary. Findings that are considered unknown, and do not yet have a pattern, that is what is of concern because qualitative research aims to find the patterns and meanings hidden behind visible data. If there is quantitative data in qualitative research, namely in the form of 
numbers, then the numbers should not be separated from the words contextually and not to reduce the meaning; 2) data presentation. Presentation of data gives the possibility of drawing conclusions and taking action. Presentation of data is used to further enhance understanding of cases and as a reference for taking action based on understanding and analysis of data presentations. Research data can be presented in the form of a description that is supported by a network matrix; 3) decision making and verification. Withdrawal of conclusions is the result of research that answers the focus of the study based on the data analysis. Conclusions are presented in the form of descriptive research objects based on research studies, 4) data analysis was performed on statements or statements made by informants. The researcher reads all the interview transcripts available and describes all experiences found in the field. Based on the efforts at the stated stage, it will be known that both the connotative denotative meaning and the implicit and explicit meaning of the statement on the topic or object. Furthermore, the description of meaning itself will show the meaning themes (meaning themes) which indicate the tendency towards the answer or understanding intended by the informants. As well as other important aspects analyzed in phenomenology are holistic and general explanations about a conversation with a research subject. From this general explanation a link must be drawn between the meanings developed on each topic discussed during the interview process (the general description of the experience).

\section{RESULTS AND DISCUSSION}

\section{The Analysis of Self-Efficacy and Classroom Management of Madrasah Ibtidaiyah Teachers}

In analyzing the self-efficacy and classroom management of Madrasah Ibtidaiyah teachers, researchers used questionnaire based on first, efficacy in teaching (instructional selfefficacy) reveals pedagogical competence. Second, disciplinary self-efficacy is used to reveal personality competencies. Third, efficacy influences decision making (efficacy to influence decision), efficacy influences school resources (efficacy to influence school resources), efficacy to enlist parental involvement, and efficacy involving community (efficacy to enlist community involvement) in line with social competence. Fourth, the efficacy of creating a positive school climate (efficacy to create a positive school climate) is in line with professional competence. Sources of efficacy include experience mastering a competency (enactive mastery experiences), experience seeing consequences that occur in others (vicarious experiences), verbal persuasion (verbal persuasion), and physiological and affective conditions (Bandura, 1997). 
The results data of the self-efficacy and classroom management analysis of Madrasah Ibtidaiyah teachers can be presented as table 1 below:

Table 1. Analysis on the self-efficacy and classroom management of madrasah ibtidaiyah teachers

\begin{tabular}{|c|c|c|c|}
\hline No & Statement & Able & Unable \\
\hline 1 & Get involved in decision making at school & $68 \%$ & $32 \%$ \\
\hline 2 & Freedom to express the things that are important in school & $88 \%$ & $12 \%$ \\
\hline 3 & $\begin{array}{l}\text { Ease of getting the materials needed in the learning process } \\
\text { (stationery, pencils, paper, etc.) }\end{array}$ & $80 \%$ & $20 \%$ \\
\hline 4 & Take part in determining the number of students in the class & $16 \%$ & $84 \%$ \\
\hline 5 & Carry out learning without the support of parents & $100 \%$ & $0 \%$ \\
\hline 6 & Keep students committed to difficult assignments & $100 \%$ & $0 \%$ \\
\hline 7 & $\begin{array}{l}\text { Have a strategy so that students can recall previous /previous } \\
\text { lessons }\end{array}$ & $100 \%$ & $0 \%$ \\
\hline 8 & Can motivate students who have difficulty doing work & $100 \%$ & $0 \%$ \\
\hline 9 & Able to influence students to learn together / in groups & $100 \%$ & $0 \%$ \\
\hline 10 & $\begin{array}{l}\text { Reducing the bad influence on the learning process in the } \\
\text { classroom }\end{array}$ & $100 \%$ & $0 \%$ \\
\hline 11 & Influencing students to do their assignments well & $100 \%$ & $0 \%$ \\
\hline 12 & Directing students to easily follow the rules in the classroom & $84 \%$ & $16 \%$ \\
\hline 13 & The ability to control bad student behavior in the classroom & $100 \%$ & $0 \%$ \\
\hline 14 & $\begin{array}{l}\text { The ability to prevent bad behavior from students in the } \\
\text { classroom }\end{array}$ & $100 \%$ & $0 \%$ \\
\hline 15 & $\begin{array}{l}\text { Provide opportunities for parents of students to be involved } \\
\text { in activities school/class. }\end{array}$ & $100 \%$ & $0 \%$ \\
\hline 16 & $\begin{array}{l}\text { Helping parents so their children can learn optimally at } \\
\text { school }\end{array}$ & $80 \%$ & $20 \%$ \\
\hline 17 & $\begin{array}{l}\text { Parents feel comfortable when meeting / consulting with the } \\
\text { teacher. }\end{array}$ & $92 \%$ & $8 \%$ \\
\hline 18 & Make the class a comfortable place for students & $100 \%$ & $0 \%$ \\
\hline 19 & Design classes so students enjoy going to school & $96 \%$ & $4 \%$ \\
\hline 20 & Help other teachers to develop their teaching abilities. & $92 \%$ & $8 \%$ \\
\hline 21 & $\begin{array}{l}\text { Collaborate with other teachers / school staff to make } \\
\text { learning effective. }\end{array}$ & $100 \%$ & $0 \%$ \\
\hline 22 & Prevent students from dropping out of school & $25 \%$ & $75 \%$ \\
\hline 23 & Prevents students from going to school lazy & $92 \%$ & $8 \%$ \\
\hline 24 & $\begin{array}{l}\text { Convince students that they are able to do all school work } \\
\text { well. }\end{array}$ & $96 \%$ & $4 \%$ \\
\hline
\end{tabular}

Table 1 showed that most Madrasah Ibtidaiyah teachers are involved in every school's decision making. But there are $32 \%$ of teachers not involved in decision making at school due to several factors, namely: there are still new teachers so they feel reluctant to get involved in decision making. Even teachers assume their role is only running the curriculum (teaching and administration) they do not need to be involved in decision making activities. Teachers in decision making include selecting instructional materials and resources, devising teaching techniques, setting grading and student assessment practices, determining the content of inservice professional development programs, establishing student discipline procedures, 
providing input on how the school budget will be spent, selecting and hiring new teachers, and school improvement planning (Ingersoll et al., 2018). Participative decision-making requires the interaction of power and influence from two faces: the administrator, the teacher, students and/ or community members on the other hand. Owens in Gemechu (2014) further explains that participative decision-making is believed to have two potential benefits: arriving at better decision and enhancing the growth and development of the school in sharing goals, improving motivation, communicating and better developing group organization's participants' skills.

Meanwhile, $12 \%$ of teachers revealed that they were not free to express important things at school, the remaining $88 \%$ stated that they could do important things that could benefit students and primarily assist in the learning process. The opportunities should be given to the teachers in expressing important things at school. It is important for conducting experiments or activities that support learning can actually improve learning outcomes. Conditions in schools are sometimes bound by strict and binding rules so that teachers are less innovative.

Furthermore, 20\% of Madrasah Ibtidaiyah teachers stated that they were difficult to get the materials needed in the learning process. Other teachers by $80 \%$ easily access the item. Coordination with staff and principals needs to be improved because the tools and media that support learning activities should be easily accessible. Then, teachers who did not participate in determining the number of students in the class were $84 \%$, while the remaining $16 \%$ stated that they participated in determining the number of students in the classroom. This is due to inadequate school conditions. The number of students is only decided by the policy maker without taking into account the ability of teachers and class conditions. From several schools it was found that the composition of students in the room was inadequate and uncomfortable so the learning process did not take place well.

All teachers stated that they did learning without the support of parents. The role of parents may be felt not very helpful in the learning process, except with activities outside of learning. In almost all school parents only assist in extracurricular activities. Parents are not involved in deciding children's learning activities at school. The involvement of parents in supporting the learning process is one important factor that supports the success of learning (Đurišić \& Bunijevac, 2017). Helping parents so their children can learn optimally at school. There are $20 \%$ of teachers who stated they did not do this. Meanwhile, $80 \%$ of teachers said they did this because it was their duty. 
There were two teachers $(8 \%)$ stated that parents were not comfortable to meet the. This might be due to parents assuming that their role is not really needed at school, some even assume it will only disrupt the teaching and learning process. $48 \%$ of teachers were unable to keep students committed to difficult assignments. Other teachers by $52 \%$ are able to do this. The Commitment for doing difficult tasks is necessary so that children can achieve optimal learning outcomes. Teachers should hold continuous reflection and enrichment, so that student commitment can grow and become an attitude that all students need to have. All teachers have a good apperception. They are able to take students into learning material by linking it to past learning or knowledge that children already have. In Fitriani's study, it was conveyed that one way to find out students' commitments was to measure their motivation (Fitriani, 2017). Apperception is needed by students to connect the knowledge they have and what will be taught. By doing apperception, it is expected that students' knowledge possessed after the learning process can be applied in real life. Teacher apperception can enhance students' interest in learning (Ardillah, 2019).

All teachers are good motivators. They use various methods so that children can do difficult tasks, for example using peer tutors, etc. The teacher considers this routine work that they must do. It is important for the teacher so that the student continues to be motivated and finish the complex tasks. Teachers are required to be able to create active and innovative learning. All teachers are able to create learning group, able to reduce the bad influence in the classroom. They tried to prevent this in various ways, for example with varied learning methods, etc. Also, teachers are able to control bad behavior in the classroom, provide opportunities for parents to be involved in class, try to make the classroom as a comfortable place for students. Learning with groups will add some benefits including helping in the process of learning, increasing motivation in learning and reducing student bad behavior in the classroom (Alfares, 2017).

Room settings, decorations, and others might be considered to make students feel comfortable. Every teacher is required so that their students have good learning achievements, able to influence students to do their assignments well, able to help other teachers to develop their abilities. This might be due to teacher working groups being formed so that they have a place to help each other. As many as $16 \%$ teachers stated that it was difficult for them to direct students to easily follow the rules. Commitment to the rules is difficult for teachers in a class consisting of students whose parents come from the middle economic class. Another teacher of $84 \%$ said that they were able to direct students to comply with class rules. 
Reminder homework or other assignments may be very helpful to the teacher so students remain committed to the task.

Furthermore, $4 \%$ of teachers stated that there is no need to design class because that is not what makes students happy to go to school. As many as $96 \%$ of other teachers said that they would make varied efforts so that students would like to go to school. $8 \%$ teachers stated that they did not need to help other teachers because of the limited number of teachers in their schools. Another teacher of $92 \%$ stated that they helped other teachers. Teachers as much as $25 \%$ make various efforts so as not to experience dropping out of school. While, $75 \%$ of teachers considered that the children who have dropped out of school are mostly caused by environmental factors. The teacher cannot prevent lazy students from going to school because of various factors including socioeconomic parents of students as much as $8 \%$. As stated by Qasem (2019) that parents' socioeconomic will affect students' academics.

Another 92\% teacher stated that he could prevent lazy students from going to school. There is one teacher (4\%) who is unable to convince students that because the teacher feels the child is good at doing the assignment. Another $96 \%$ teacher still needs to do this. Arellado \& Palma (2016) said that the first three reasons implied were bombarded with multiple tasks they have to go through, as these require time management to cope with the challenges of getting things done, while the last reasons connote laziness. Teacher's monitoring contributed much to the wholesome attitude of the students. They were motivated to improve their work, probably because they were inspired by the constructive criticism they received. This means that self-efficacy and classroom management of Madrasah Ibtidaiyah teachers are good, because the teachers have four teachers competences, namely professional competence, personality competence, social competence, and pedagogical competence.

\section{Analysis on Personality of Madrasah Ibtidaiyah Teachers}

Based on the interviews with a number of Madrasah Ibtidaiyah teachers in September 2018, it is said that the succes of student learning is because of the teachers are able to motivate students well. So students are excited and work hard in learning. Sometimes teachers also experience difficulties in creating effective and efficient learning. This is because the teacher does not prepare the subject matter properly. According to him, they were too busy with administrative tasks as a teacher.

Regarding the learning methods used in class, the teachers stated that they were flexible in using the learning methods. Sometimes they use the group discussion method, not infrequently they also use the direct learning method. According to him, the use of learning methods is adjusted to the characteristics of students and the material being taught. Thus, it is 
expected that student learning outcomes can be improved. The teachers also realize that in the learning process they do not always give interesting assignments to students, so students sometimes feel bored in doing the tasks given by the teacher during the learning process.

In addition, most teachers also admit that they have not fully mastered the basic concepts of mathematics well. Sometimes the teacher cannot give concrete examples that can illustrate these mathematical concepts. So that students have difficulty in understanding mathematics subject matter delivered by the teacher. However, the teachers have tried to create fun and enjoyable learning by using a variety of models, methods and learning strategies that are appropriate to the characteristics of students, so students are enthusiastic in following the learning process. Therefore, the success of student learning is not only determined by the intelligence of the teacher in managing learning in the classroom, but also determined by how much enthusiasm and hard work of students in learning. Thus, the teacher's role is very dominant in supporting student learning success. The teacher not only acts as a facilitator, but the teacher also acts as a motivator for students.

Based on the explanation above, the results of the study indicate that the self-efficacy, classroom management, and personality of Madrasah Ibtidayah teachers in the city of South Tangerang are in the good category. Self-efficacy, class management, and teacher personality are very influential on the effectiveness and success of teachers in the classroom learning process (Yuliyanto, Turmudi, Agustin, Putri, \& Muqodas, 2019); (Othman, 2009). In addition, teachers who have good efficacy will also have a positive impact on their students (Ebuenga-Amora, 2016) and will be responsible for their achievements as teachers (Evers, Brouwers, \& Tomic, 2002). Furthermore, Arif, Rashid, Tahira, \& Akhter (2012) explained that some strategies for the development of teachers' personality to be the part of teacher education programs. Symon (1947) described that the quality of personality must be taken into account to the selection of candidates for teaching profession.

The teacher's locus of control needs to be improved because of the vital role of the teacher for making the success of student learning. According to Angelova (2016), there are three factors that affected to the personality, namely family status, professional activity, and education. Teachers who have a good internal locus of control will easily realize their role and do not consider people outside themselves as the cause of failure. Locus of control because as part of personality competence needs to be trained so that the impact caused also affects student learning outcomes, even teachers will avoid the attitude of blame, anxiety, and hurry. Locus of control and self-efficacy are important behavioral constructs which can determine the effectiveness of teachers in different ways. The three constructs i.e. Locus of control, self- 
efficacy and commitment play major role in individual and organizational effectiveness (Hans et al., 2017).

\section{CONCLUSION}

Based on the results of research and discussion that has been described can be concluded that the self-efficacy, classroom management, and personality of Madrasah Ibtidayah teachers in the city of South Tangerang are in the good category. Self-efficacy, class management, and teacher personality are very influential on the effectiveness and success of teachers in the learning process in the classroom. Therefore, the development of teacher's selfefficacy, classroom management, and personality of Madrasah Ibtidayah teachers should get more attention from stakeholders. Provision of training or workshop to hone this ability needs to be increased again.

\section{REFERENCES}

Alfares, N. (2017). Benefits and Difficulties of Learning in Group Work in EFL Classes in Saudi Arabia. English Language Teaching, 10(7), 247. https://doi.org/10.5539/elt.v10n7p247.

Angelova, N. V. (2016). Locus of control and its relationship with some social-demographic factors. Psychological Thought, 9(2), 248-258. https://doi.org/10.5964/psyct.v9i2.179.

Ardillah, A. (2019). Teacher's apperception to enhance students' interest in learning English at first year of SMPN 1 Wringinanom Gresik. UIN Sunan Ampel.

Arellado, M. A. F., \& Palma, B. S. (2016). Students ' Reasons for Not Doing Their Assignment. International Journal of Multidisciplinary Reasearch and Development, 3(4), 318-320.

Arif, M. I., Rashid, A., Tahira, S. S., \& Akhter, M. (2012). Personality and Teaching: An Investigation into Prospective Teachers ' Personality. International Journal of Humanities and Social Science, 2(17), 161-171.

Bandura, A. (1997). Self-Efficacy: An Exercise of Control. New York W.H. Freeman and Company.

Brouwers, A., \& Tomic, W. (2000). A longitudinal study of teacher burnout and perceived self-e \$ cacy in classroom management. Teaching and Teacher Education, 16, 239253.

Dull, E., \& Reinhardt, S. P. (2014). An analytic approach for discovery. In CEUR Workshop Proceedings (Vol. 1304, pp. 89-92).

Đurišić, M., \& Bunijevac, M. (2017). Parental involvement as a important factor for successful education. Center for Educational Policy Studies Journal, 7(3), 137-153.

Ebuenga-Amora, M. (2016). Teachers'organizational commitment, teaching efficacy belief and level of performance in relation to their pupils' attitude towards mathematics. Education, 2(2), 49-56. http://apiar.org.au/wpcontent/uploads/2016/08/6_APJCECT_APCAR_BRR722_EDU_49-56.pdf. 
Erawati, M. (2012). Profil dan Faktor-faktor yang memengaruhi efikasi guru MI peserta Dual Mode System. Jurnal Inferensiai, 6(2), 417-440. http://muna.staff.iainsalatiga.ac.id/wp-content/uploads/sites/65/2013/02/efikasi-gurumadrasah-muna-inferensi.pdf.

Evers, W. J. G., Brouwers, A., \& Tomic, W. (2002). Burnout and self-efficacy: A study on teachers' beliefs when implementing an innovative educational system in the Netherlands. British Journal of Educational Psychology, 72(2), 227-243. https://doi.org/10.1348/000709902158865.

Evertson, C. M., \& Neal, K. W. (2006). Looking into Learning-Centered Classrooms Implications for Classroom Management Looking into Learning-Centered Classrooms Implications for Classroom Management (Issue July). http://www.nea.org/tools/behavior-contracts-how-to-write-them.htm.

Fitriani. (2017). Student Commitment to Do Lecture Task Observed from Motivation to Achievement. Advances in Social Secience, Education and Humanities Reasearch (ASSEHR), 66(Yicemap), 176-180. https://doi.org/10.2991/yicemap-17.2017.30.

Frazier, R., Bendixen, L. D., \& Hoskins, W. J. (2019). Exploring tThe Role oOf Self-Efficacy iIn Prospective Teachers' career Decision-Making. Journal of Ethnographic \& Qualitative Research, 13(4).

Friedman, I. A., \& Kass, E. (2002). Teacher self-efficacy: A classroom-organization conceptualization. Teaching and Teacher Education, 18(6), 675-686. https://doi.org/10.1016/S0742-051X(02)00027-6.

Gemechu, D. (2014). The Practices of Teachers' Involvement in Decision-Making in Goverment Secondary Schools of Jimma Town [Jimma University]. In Pediatric Physical Therapy (Vol. 22, Issue 1). https://doi.org/10.1016/s1013-7025(09)70018-1.

Gibson, H., \& Dembo, M. . (1984). Teacher efficacy: a construct validation. Jounal of Educational Psychology, 76(4), 569-582. http://dx.doi.org/10.1037/00220663.76.4.569.

Hans, A., Deshpande, A., Pillai, A. E., Fernandes, C. J., Arora, S., Kariya, P., \& Uppoor, A. (2017). A Study on Self-Efficacy , Locus of Control and Commitment in Select Private Management Colleges in Oman. Amity Journal of Management Research, 2(1), 1-9.

Hofstede, G. (1991). Culture and Organizations: Software of the mind. London: McGrawHill.

Honicke, T., \& Broadbent, J. (2016). The influence of academic self-efficacy on academic performance: A systematic review. Educational Research Review, 17, 63-84.

Ingersoll, R. M., Sirinides, P., \& Dougherty, P. (2018). Leadership Matters Teachers' Roles in School Decision Making and School Performance. American Educator, Spring, 1317.

http://repository.upenn.edu/cpre_workingpapers/15.\%0Ahttps://eric.ed.gov/?id=EJ11 73452\%0Ahttp://repository.upenn.edu/cpre_workingpapers/15.

Kim, L. E., Jorg, V., \& Klassen, R. M. (2019). A Meta-Analysis of the Effects of Teacher Personality on Teacher Effectiveness and Burnout. Educational Psychology Review, 31, 163-195. https://doi.org/https://doi.org/10.1007/s10648-018-9458-2.

Moran, Megan, T., Hoy, \& Woolfolk, A. (2001). Teacher Efficacy: Capturing An Elusive Construct. Teeaching and Teacher Education, 783-805. 
Nunn, G. \& Jantz, P. (2009). Factors within Response to Intervention Implementation Training Associated with Teacher Efficacy Beliefs. Education, 129, 599-607.

Othman, F. B. (2009). A Study on Personality that Influences Teaching Effectiveness.

Panadero, E., Jonsson, A., \& Botella, J. (2017). Effects of self-assessment on self-regulated learning and self-efficacy: Four meta-analyses. Educational Research Review, 22, 74-98. doi:https://doi.org/10.1016/j.edurev.2017.08.004.

Phares, E. (1976). Locus of Control in Personality. General Learning Press, Moristown, N.J.

Qasem, L. (2019). Active Parental Involvement Relationship With Socioeconomic Status, and Its Impact on Students' Academic Performance. International Journal Pedagogy of Social Studies, 3(2), 123-132. https://doi.org/10.17509/ijposs.v3i2.15570

Rosyidah \& Ratnasari. (2013). Analisis Hubungan Faktor Pembentuk Efikasi Mengajar Guru Sekolah Dasar (SD) di Kabupaten Jember. Jurnal Statistika Institusi Teknologi Sepuluh Nopember.

Rotter, J. B. (1966). Generalized expectancies for internal versus external control of reinforcement. Psychological Moographs, 80(1).

Skaalvik, E. M., \& Skaalvik, S. (2007). Dimensions of Teacher Self-Efficacy and Relations With Strain Factors, Perceived Collective Teacher Efficacy, and Teacher Burnout. Journal of Educational Psychology, 99(3), 611-625. https://doi.org/10.1037/00220663.99.3.611.

Stajkovic, A. D., Bandura, A., Locke, E. A., Lee, D., \& Sergent, K. (2018). Test of three conceptual models of influence of the big five personality traits and self-efficacy on academic performance: A meta-analytic path-analysis. Personality and individual differences, 120, 238-245.

Symonds, P. M. (1947). Personality of the Teacher. The Journal of Educational Research, 40(9), 652-661. https://doi.org/10.1080/00220671.1947.10881564.

Veronika, L., Lívia, F., Anna, T., \& Eva, M. (2018). Teachers ' Self-Efficacy as a Determinant of Lesson Management Quality. TEM Journal, 7(3), 662-669. https://doi.org/10.18421/TEM73-25.

Williams, D. M., \& Rhodes, R. E. (2016). The confounded self-efficacy construct: Conceptual analysis and recommendations for future research. Health psychology review, 10(2), 113-128.

Yoo, J. H. (2016). The effect of professional development on teacher efficacy and teachers' self-analysis of their efficacy change. Journal of Teacher Education for Sustainability, 18(1), 84-94.

Yuliyanto, A., Turmudi, T., Agustin, M., Putri, H. E., \& Muqodas, I. (2019). The Interaction Between Concrete-Pictorial-Abstract (CPA) Approach and Elementary Students' Self-Efficacy In Learning Mathematics. Al Ibtida: Jurnal Pendidikan Guru MI, 6(2), 244-255.

Zimmerman, B. J., Schunk, D. H., \& DiBenedetto, M. K. (2017). The role of self-efficacy and related beliefs in self-regulation of learning and performance. Handbook of competence and motivation: Theory and application, 313. 